\title{
ONCHOCERCA RAMACHANDRINI N. SP. FROM THE WARTHOG IN CAMEROON ${ }^{1}$
}

\author{
O. BAIN*, G. WAHL ${ }^{* *}$, A. RENZ** \\ With THE TECHNICAL ASSISTANCE OF R. TCHEPRAKOFF
}

\begin{abstract}
SUMMARY
$O$. ramachandrini $\mathrm{n}$. sp., a parasite of the subcutaneous tissues of the feet of Phacochoerus aethiopicus in Cameroon, is described. The female has 3 to 5 giant coelomocytes which form swellings in the anterior part of the body. Together with $O$. dewittei Bain, Ramachandran, Petter et Mak, 1977, this species constitues a small

group of parasites of the Suidae, which are morphologically well characterized, and of which the African species seems to be the most primitive one (conservation of a female cuticle without transverse ridges).

\section{RÉsumé: Onchocerca ramachandrini n. sp., chez le phacochère au Cameroun.}

Description de $O$. ramachandrini $\mathrm{n}$. sp., parasite du tissu souscutané des pattes de Phacochoerus aethiopicus au Cameroun. La femelle a 3 à 5 coelomocytes géants qui font des renflements dans la région antérieure du corps. Cette espèce et $O$. dewittei Bain,

Ramachandran, Petter et Mak, 1977, en Malaisie, forment un petit groupe parasite de suidés, bien caractérisé morphologiquement, où l'espèce africaine apparait la plus primitive (persistance d'une cuticule sans côtes transversales chez la femelle).
\end{abstract}

Adult worms of a new Onchocerca species were found in warthogs, during a survey of game animals in February 1992 in a hunting lodge on the river Vina du Nord (« Campement de Vogzum »), $160 \mathrm{~km}$ to the North-East of Ngaoundéré, North-Cameroon.

The rate of parasitism was high: three warthogs infected out of 6 examined. The filariae were found in the subcutaneous tissues of the front and hind feet, in the metacarpal and metatarsal regions and once in the radial region. The worms were loosely looped on the inside of the skin. Small nodules containing more or less degenerated fragments of these worms were also seen.

Microfilariae similar to those found in the uteri of the female worms were found in the skin of the warthogs (neck,

1. This investigation was supported by the Science and Technology for Development Programme of the European Community, Contract $n^{\circ}$ TS2/0184-D (AM).

* Biologie Parasitaire, Protistologie, Helminthologie, Muséum national d'Histoire naturelle, CNRS URA 114, 61, rue Buffon, F 75231 Paris.

** Institut für Tropenmedizin, Eberhard-Karls-Universität, Wilhelmsträsse 27, D 7400 Tübingen, Germany.

*** Universität Hohenheim, Fachgebiet Parasitologie, Postfach 700562,7000 Stuttgart 70, Germany.

Accepté le : 19 février 1993. back, feet). They coexisted with another species of dermal microfilariae, which was more abundant but of which the adults are presently unknown.

\section{MATERIAL}

Adult worms (collection number $48 \mathrm{SE}$ ): - the female holotype. It was extracted from alcohol-preserved skin after short digestion with pepsin. It was obtained in two pieces, but seems complete. - The male allotype. - Female paratypes. These are five anterior fragments with microfilariae (three long fragments with head, two short ones without head) and two posterior fragments. - One male paratype.

Dermal microfilariae, mounted in glycerin: one slide (collection number $46 \mathrm{SE}$ ). Dermal microfilariae of the unknown species are also present on this slide.

All the specimens are deposited in the collection of the MNHN, Paris.

\section{DESCRIPTION}

The body is slightly curled in both sexes. Head: external labial papillae arranged in a rectangle stretched in the 
median plane. Cephalic papillae arranged in a rectangle slightly stretched in the lateral plane. Oesophagus not divided.

Female: 3 to 5 swellings on the first 2 to $3 \mathrm{cms}$ of the anterior body. Every swelling is caused by one big ventral coelomocyte (Fig. $1 \mathrm{~B}, L, M$ ). The cuticle has transverse well defined striae in the first 5 to $6 \mathrm{mms}$ of the anterior region, which are poorly marked more posteriorly; no transverse ridges, but discontinuous longitudinal crests (Fig. $1 \mathrm{H}$, $I, K)$. The uteri are straight and parallel to each other (Fig. $1 \mathrm{M}$ ).

Male : anterior region without body-swellings. Transverse striae of the cuticule are present but inconspicuous. The arrangement of the caudal papillae is shown in Fig. $2 \mathrm{H}$, $I, G$; the papillae are arranged symmetrically, there are 5 pairs near the cloaca and 6 pairs on the distal half of the tail; the second most distal pair is cuticularized and conical and corresponds to the phasmids, with the phasmidial pore at its base. The last pair is situated on the tip of the tail.

Uterine microfilariae: head slightly attenuated when the hook is seen from above and blunt when hook is seen from the side. Tail curved. Last caudal nucleus elongated or small and round. After fixation, the uterine and the dermal microfilariae may be $\mathrm{S}$ shaped.

\section{Measurements}

Female holotype: $128 \mathrm{~mm}$ long and $210 \mu \mathrm{m}$ wide. There are 3 body-swellings which are at 14,100-20,700-30,600 $\mu \mathrm{m}$ from the apex. Nerve ring at $250 \mu \mathrm{m}$ from the apex. Oesophagus $1,250 \mu \mathrm{m}$ long. Vulva at $650 \mu \mathrm{m}$ from the apex. Tail $170 \mu \mathrm{m}$ long. Female paratypes: body-swellings at $6,300-11,100-16,500-22,500 \mu \mathrm{m}$ respectively from the apex (measurements on one of the anterior fragments). Cuticle 15-20 $\mu \mathrm{m}$ thick. Nerve ring at 250-270 $\mu \mathrm{m}$ from apex. Oesophagus $1,480-1,510 \mu \mathrm{m}$ long. Vulva at $550-800 \mu \mathrm{m}$ from apex; ovejector $6,000 \mu \mathrm{m}$ long (measured on one specimen). Tail 170-180 $\mu \mathrm{m}$ long.

Male allotype and male paratype: $34-32.3 \mathrm{~mm}$ long and 72-65 $\mu \mathrm{m}$ wide. Nerve ring at $175-190 \mu \mathrm{m}$ from apex. Oesophagus $1,050-1,000 \mu \mathrm{m}$ long. Left spicule $220-240 \mu \mathrm{m}$ long with handle 100-120 $\mu \mathrm{m}$ long. Right spicule 78-78 $\mu \mathrm{m}$ long. Tail 105-125 $\mu \mathrm{m}$ long.

Microfilariae from uteri of holotype and paratypes: body 290 à $325 \mu \mathrm{m}$ long $(325,320,320,315,290,315,320,315$, $305,310,320 \mu \mathrm{m})$ and $7-7,5 \mu \mathrm{m}$ wide. Cephalic space $10-12 \mu \mathrm{m}$ long. Nerve ring at $75 \mu \mathrm{m}$ from the apex. Last caudal nucleus at $10-15 \mu \mathrm{m}$ from tip tail. Dermal microfilariae: $305,287,318 \mu \mathrm{m}$ long and $7 \mu \mathrm{m}$ wide.

\section{DISCUSSION}

The genus Onchocerca comprises the 24 species listed in the most recent dichotomous key (Bain, 1981), and in addi- tion O. stilesi Eberhard, 1979, the description of which has been completed (Bain, 1993), O. denkei Bain, Vassiliades et Delbove, 1982 and $O$. alcis Bain et Rehbinder, 1985.

Of all species only two have females without cuticular transverse ridges as in our specimens. These are $O$. railliet $i$ Bain, Muller, Khamis, Guilhon, Schillborn van Veen, 1976 et O. bohmi (Supperer, 1953). Both are parasites of the Equidae, the first in Africa, the second in Europe. These two species are distinct from our material due to several characters: $O$. raillieti has a long oesophagus $(\geq 2 \mathrm{~mm}$ ) with a well developed glandular part, the arrangement of its caudal papillae is similar to the primitive spirurid pattern, its spicules are bigger than in our specimens (440-500 et $150-170 \mu \mathrm{m}$, for the left and the right spicules respectively) and it has a smaller microfilaria $(180-215 / 4 \mu \mathrm{m})$. $O$. bohmi has a female cuticle without longitudinal crests, the left spicule is bigger $(275-300 \mu \mathrm{m})$, and its microfilaria has a long caudal filament.

If one disconsiders the morphology of the female cuticle, the species in Sus scrofa jubatus in Malaisia, O. dewittei Bain, Ramachandran, Petter et Mak, 1977 is particularly close to the specimens from the warthog: oesophagus shorter than $2 \mathrm{~mm}$ and not divided, anterior vulva, arrangement of caudal papillae rather similar to that of the primitive spirurid pattern, papillae of the head arranged in an evolved pattern (the external labial papillae form a rectangle stretched in the median plane). But this species has transverse ridges on the female cuticle and its microfilaria is smaller (228-248 $\mu \mathrm{m}$ vs 290-325 $\mu \mathrm{m})$.

Moreover, these three species, like all other Onchocerca species, do not have the body-swellings caused by coelomocytes as in our female specimens.

The specimens from the warthog are therefore a new species Onchocerca ramachandrini n. sp., which we dedicate to Dr. C. P. Ramachandran, Secretary of the Steering Committee of Filariases, from the World Health Organization.

\section{CONCLUSIONS}

O. ramachandrini $\mathrm{n}$. sp., from the warthog in Cameroon, seems to constitute, together with $O$. dewittei in Malaisia, a small group of parasites of the Suidae, which show some primitive characters (anterior vulva, arrangement of caudal papillae) along with more evolved ones (oesophagus shorter than $2 \mathrm{~mm}$ and not divided, arrangement of the papillae of the head). The fact that the African species has conserved a cuticle without transversal ridges, like the " ancestral » species $O$. raillieti of the donkey in Africa, is in agreement with the hypothesis that the genus has spread from the Ethiopian region (Bain, 1981). 


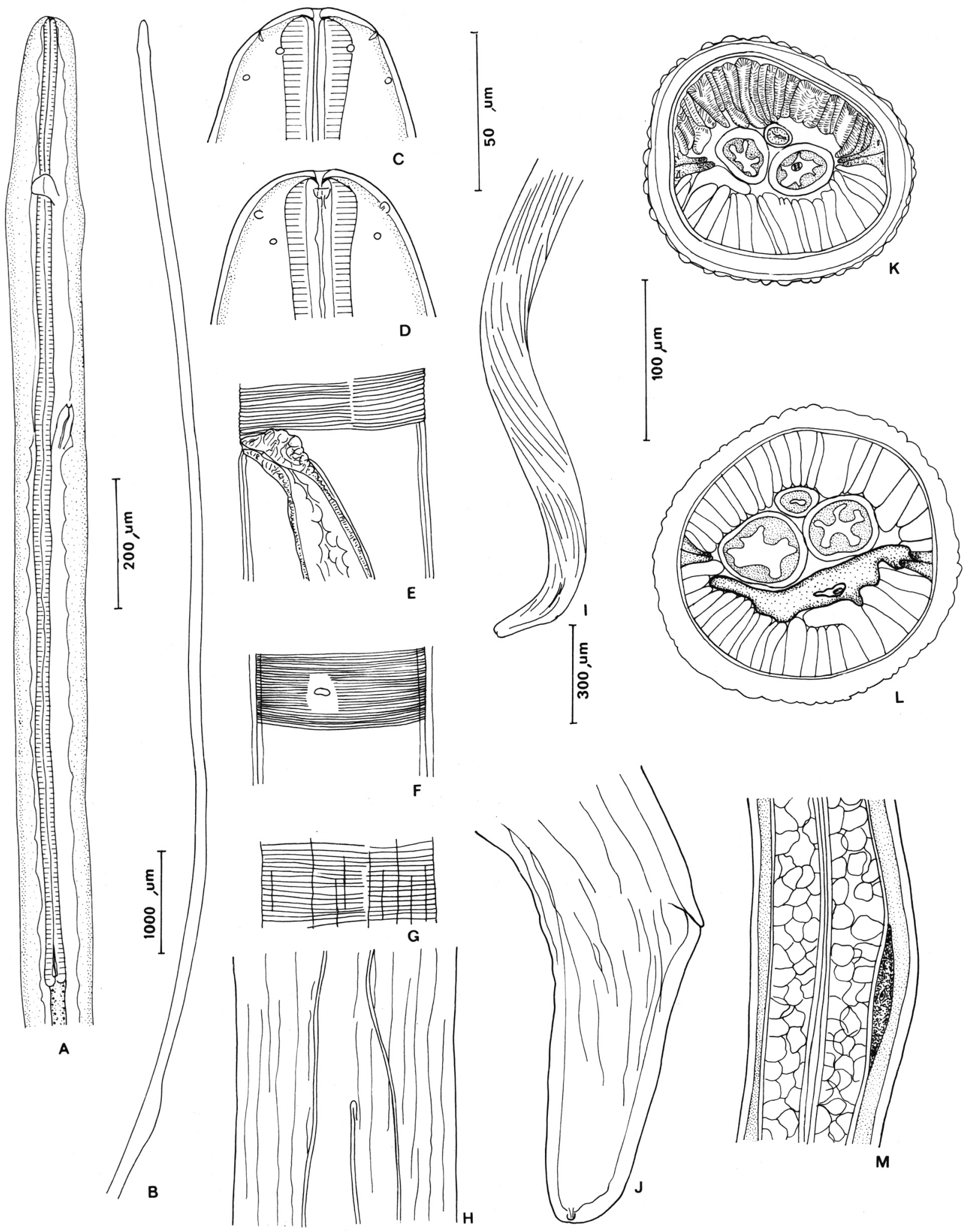

FIG. 1. - Onchocerca ramachandrini $\mathrm{n}$. sp., female. A: anterior region, latero-ventral view; B: anterior region including the first bodyswelling; C, D: head, median and lateral views, respectively; E, F: cuticle with transversal striae at the level of the vulva, lateral and median views, respectively; G: cuticle with longitudinal crests and transversal striae at $5,250 \mu \mathrm{m}$ from head, lateral view; $\mathrm{H}$ : idem, at the level of the fusion of the uteri; I: posterior region; J: tail, lateral view; K: cross-section of the body, anterior to the first swelling at $6,100 \mu \mathrm{m}$ from apex; L: idem, in the middle of the first swelling with one giant coelomocyte; M: idem, right lateral view (Scales: A, M, $200 \mu \mathrm{m}$; B, 1,000 $\mu \mathrm{m}$; C, D, $50 \mu \mathrm{m}, \mathrm{E}, \mathrm{F}, \mathrm{G}, \mathrm{H}, \mathrm{J}, \mathrm{K}, \mathrm{L}, 100 \mu \mathrm{m} ; \mathrm{I}, 300 \mu \mathrm{m}$ ). 


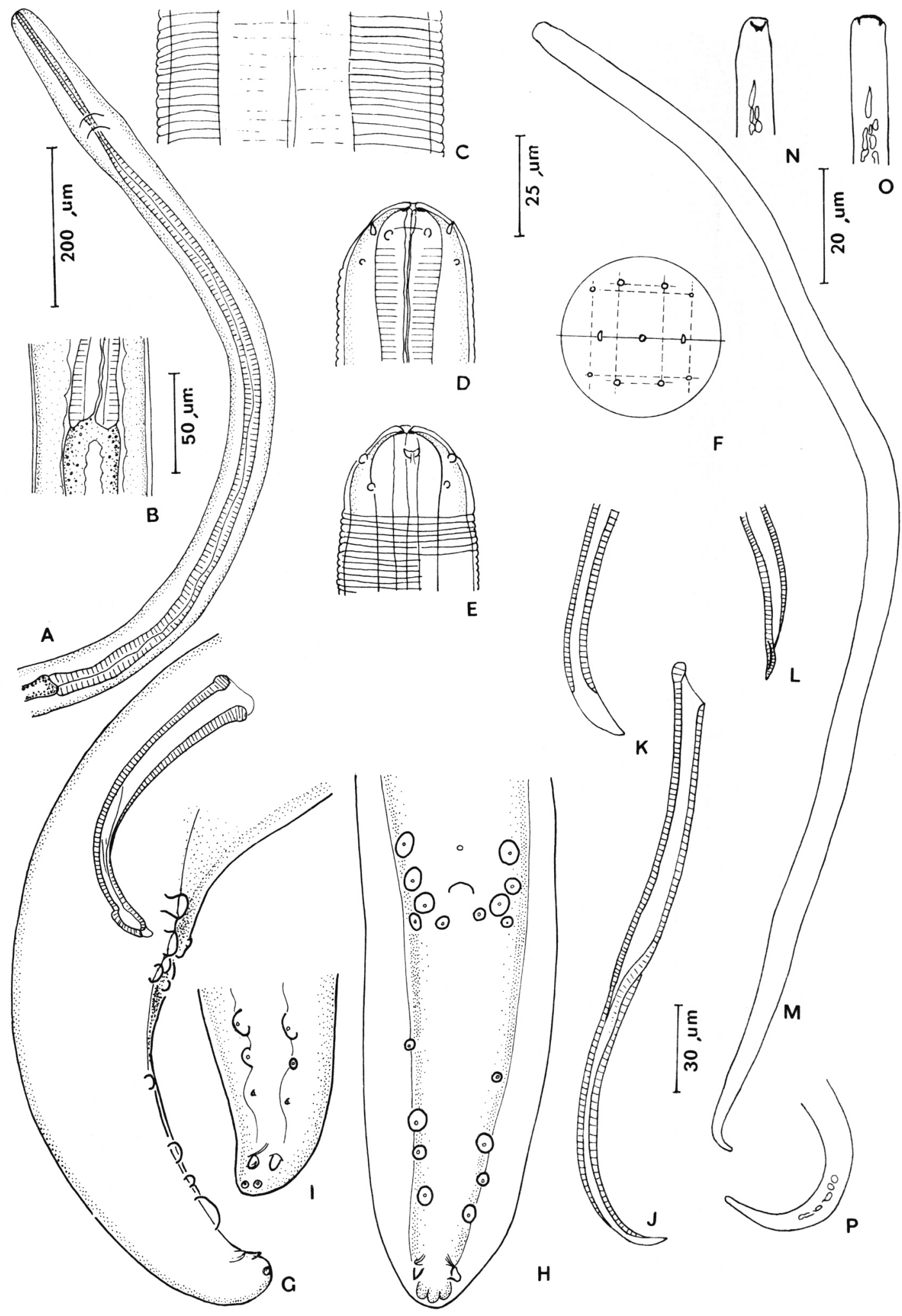

FIG. 2. - Onchocerca ramachandrini n.sp., A to L, male allotype. A: anterior region; B: region of the oesophagal-intestinal junction; C: cuticle and lateral chord at mid-body, lateral view; D, E, F: head, in median view, lateral view, and en face view respectively; G: tail, lateral view; H: idem, ventral view; I: idem, extremity; J: left spicule; K: idem, distal extremity, lateral view; L: idem, ventral view. M to P, uterine microfilaria. M: general aspect; N, O: anterior extremety, hook seen from above or from the side, respectively; P: caudal extremity (Scales: A, $200 \mu \mathrm{m}$; B, $50 \mu \mathrm{m}$; C, D, E, G, H, I, K, L, M, $25 \mu \mathrm{m}$; N, O, P, $20 \mu \mathrm{m}$; J, 30 $\mu \mathrm{m}$; F, diagrammatic representation). 
The giant coelomocytes and the body-swellings in $O$. ramachandrini, which were so far unknown in the genus, are characters playing a role in the copulation, which have appeared in different phylogenetic lines (Bain et Chabaud, 1988) and are therefore without profound phylogenetic significance.

\section{REFERENCES}

Bain O. : Compléments morphologiques sur Onchocerca stilesi Eberhard, 1979. Ann. Parasit. Hum. Comp. 1993, in preparation.

Bain O. : Le genre Onchocerca: hypothèses sur son évolution et clé dichotomique des espèces. Ann. Parasitol. Hum. Comp., 1981, 56, 503-526.

Bain O., Vassiliades G., Delbove P. : Une nouvelle onchocerque, parasite de bovin domestique, au Sénégal. Ann. Parasitol. Hum. Comp., 1982, 57, 587-591.

Bain O., Rehbinder C. : Nouvelle onchocerque, Onchocerca alcis n. sp., parasite de l'élan, Alces alces, en Suède, Ann. Parasitol. Hum. Comp., 1986, 61, 447-455.

Bain O., Chabaud A. G. : Un appareil favorisant l'accouplement des filaires : les renflements de la région antérieure du corps. Ann. Parasitol. Hum Comp., 1988, 63, 376-379.

Eberhard M. L. : Studies on the Onchocerca (Nematoda: Filarioidea) found in cattle in the United States I. Systematics of $O$. gutturosa and $O$. lienalis with a description of $O$. stilesi sp. n. J. Parasit. 1979, 65, 379-388. 